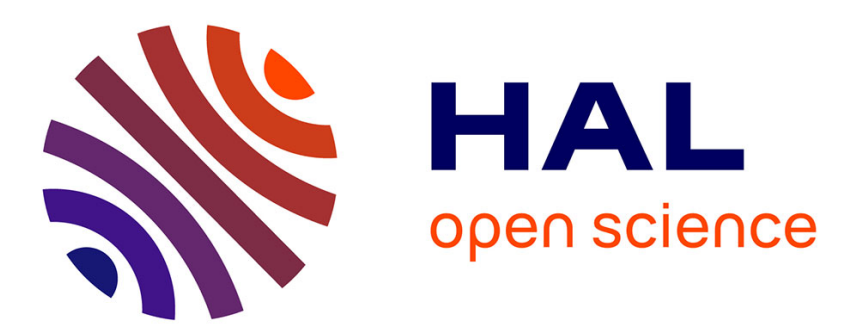

\title{
Labour relations quality and productivity: An empirical analysis on French firms
}

Gilbert Cette, Nicolas Dromel, Rémy Lecat, Anne-Charlotte Paret

\section{To cite this version:}

Gilbert Cette, Nicolas Dromel, Rémy Lecat, Anne-Charlotte Paret. Labour relations quality and productivity: An empirical analysis on French firms. 2012. halshs-00721296

\section{HAL Id: halshs-00721296 \\ https://shs.hal.science/halshs-00721296}

Submitted on 27 Jul 2012

HAL is a multi-disciplinary open access archive for the deposit and dissemination of scientific research documents, whether they are published or not. The documents may come from teaching and research institutions in France or abroad, or from public or private research centers.
L'archive ouverte pluridisciplinaire HAL, est destinée au dépôt et à la diffusion de documents scientifiques de niveau recherche, publiés ou non, émanant des établissements d'enseignement et de recherche français ou étrangers, des laboratoires publics ou privés. 


\section{Documents de Travail du Centre d'Economie de la Sorbonne}

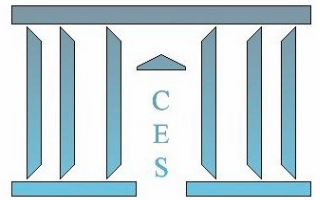

Labour relations quality and productivity :

An empirical analysis on French firms

Gilbert CetTe, Nicolas Dromel, Rémy LeCAT, Anne-Charlotte PARET

2012.52

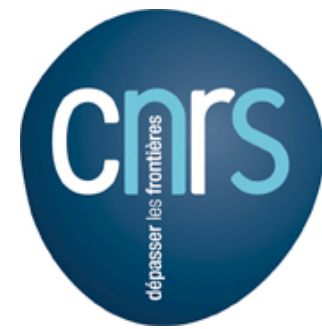




\title{
Labour relations quality and productivity: An empirical analysis on French firms
}

\author{
Gilbert Cette $^{\mathrm{a}^{*}}$, Nicolas Dromel ${ }^{\mathrm{b}}$, Rémy Lecat ${ }^{\mathrm{c}}$, Anne-Charlotte Paret ${ }^{\mathrm{d}}$
}

July 23, 2012

\section{Abstract:}

This analysis characterizes empirically how good labour relations can alleviate the negative impact on productivity of regulatory constraints or workforce opposition. Our evidence of good labour relations lies in the existence of binding collective agreements, at the firm or at the industry level. The estimations are based on a unique dataset collected by the Banque de France about the obstacles French firms may face in increasing their utilisation of production factors. Data are an unbalanced sample of 7,441 observations, corresponding to 1,545 companies, over the period 1991-2008.

Our main results may be summarised as follows: i) 'workforce or union opposition' interacted with 'regulatory constraints' has a negative significant impact on total factor productivity (TFP). Regulatory constraints would become really binding when workers or unions use them as a tool to oppose management's decisions; ii) 'regulatory constraints' interacted with 'branch or firm agreement' has a positive significant impact on TFP. These agreements, which can only be obtained if labour relations are supportive, would be used by firms to offset the negative impact of regulatory constraints.

These results confirm that labour relations quality, at the branch or the firm levels, is an important factor of productive performance.

Keywords: Labour relation, collective bargaining, trade unions, productivity JEL Classification: J53, J52, J51

a: Banque de France and Université de la Méditerranée (DEFI) [gilbert.cette@ banque-france.fr]

b: Paris School of Economics, CNRS [nicolas.dromel@parisschoolofeconomics.eu]

c: Banque de France [remy.lecat@banque-france.fr]

d: Banque de France, ENSAE [anne.charlotte.paret@ensae.fr]

*: Corresponding author.

The authors would like to thank, without implicating, Philippe Askenazy, Pierre Cahuc, Romain Duval, Denis Fougère, Eva Moreno-Galbis, Thomas Piketty, seminar participants at the Banque de France, at the Paris School of Economics, as well as participants to the T2M 2012 and AFSE 2012 conferences for helpful comments. Antoine Bonleu and Claire Martin are acknowledged for their help in data collection. The views expressed herein are those of the authors and do not necessarily reflect the views of the institutions they belong to. 


\section{Introduction}

A large amount of literature has been analysing the impact of worker voices, and more generally of work relations quality, on firm performances. An important part of this literature characterizes work relations by representative institutions, such as unions or works councils, and investigates their impact on firm performances. These performances are themselves characterized by labour productivity, total factor productivity or profitability. As a matter of fact, these studies do not really provide a unified and simple message.

Concerning the effect of unionization, the literature surveys from Hirsch (2007) and Morikawa (2010) show that while a majority of analyses find a positive impact on productivity, some do find a nonsignificant impact or even a negative one. For example, both on US individual firm data, Brown and Medoff (1978) find a positive impact and Clark (1984) a negative one. On the same type of data, Cooke (1994) or Black and Lynch (2001) give an explanation of this contrast: they find a positive impact of unionization on productivity only in firms where the employer adopts some human resource practices that promote joint decision with incentive-based compensation, and a negative impact in firms that maintain more traditional labour management relations. The impact of unionization on average wage is found to be usually positive, but the impact on firm profitability is ambiguous, positive or negative depending on the study.

The survey from Addison (2005) also highlights contrasted conclusions in the literature regarding the impact of works councils on productivity. Addison et al. (2000) on German and British firms and Addison et al. (2001) on German firms obtain a positive impact in large firms only. Fairris and Askenazy (2010) find, on French firms, no evidence of a positive impact of works councils on firm productivity and even some limited evidence of a negative effect. Hübler and Jirjahn (2003) provide an empirical explanation of these different results. Based on German firms, their study shows a positive impact of works councils on productivity only within firms covered by collective agreements. This empirical result is actually in line with the theoretical paper from Freeman and Lazear (1994) which shows that works councils can improve firm productivity under certain conditions: "There are potential net social gains from works councils. But to work best and gain these potential benefits, the rules governing councils must be carefully written to bound the power of labor and management and 'fit' the broader labor system in which councils must function". It appears that works councils can improve firm productivity only in situations where the quality of labour relations is good enough to prevent some risks of inefficiency. The positive impact on productivity results in fact from the interaction between works councils and these good labour relations, works councils being however a negative productivity factor if taken individually.

The large literature on the quality of labour relations focused on indicators such as strikes (Kleiner, Leonard and Pilarski, 2002; Mas, 2008), grievance fillings (Ichniowski, 1986; Katz, Kochan and Gobeille, 1983), absenteeism (Katz, Kochan and Gobeille, 1983), tough union leaders (Lazear, 1995; Kleiner, Leonard and Pilarski, 2002) and labour climate surveys among managers or workers of a specific plant (Katz, Kochan and Gobeille, 1983; Deery and Roderick 2005; Katz, Kochan and Keefe, 1987). These papers support the negative impact of a deteriorated labour climate on productivity or product quality. More precisely, Deery and Iverson (2005) point out the building blocks of a good labour climate, as reflected by an employee survey: in particular, the union's willingness to adopt an integrative approach to bargaining and the management's willingness to share information freely with the union. However, these papers are based on case studies (different plants of the same firm in automobile, aircraft, paper mills...) and do not address the impact of firm or branch agreements or of the interactions between these agreements and labour relations. 
Our aim is to characterize the impact on productivity of good labour relations. In France, large margins of improvement in labour relations quality may exist, as compared to other countries. Trade union density is the lowest among OECD countries (7.6\% in 2008 for 18.6\% in Germany according to the OECD) and labour regulations at the national level rarely stem from union-employers negotiation. Aghion et al. (2011) highlight that in a cross-section of countries, state regulation of labour markets is negatively correlated with the quality of labour relations. They argue that state regulation crowds out the possibility for workers to experiment negotiation and learn about the potential cooperative nature of labour relations. This mechanism seems to be particularly relevant for France, where state intervention in the labour market regulation is widespread and pregnant.

Our empirical analysis is based on a unique survey of French firms, about the obstacles they may face in increasing their production factor utilisation: the survey on factor utilisation degrees (FUD hereafter). We merge these data with FiBEn, another individual company dataset collected by the Banque de France. FiBEn is a very large database that includes balance sheets and profit and loss accounts from annual tax statements, and can be used to compute total factor productivity (TFP) and changes in output. The FUD survey has been carried out every year since 1989 by the Banque de France at the plant level. It not only provides rich insights about firm-level factor utilisation, but also a unique appraisal of rigidities faced by firms in increasing their capital workweek. Firms are directly asked to declare the presence of such rigidities, and to characterize their legal, social or technical nature. More precisely, entrepreneurs answered the following question: «If you had to increase your capital operating time, and if your sales potential could justify it, would you meet obstacles or brakes such as... ? ». The considered obstacles are: worker opposition, union opposition, absence of qualified workforce, bottleneck on commodities or supply, technical obstacles, legal or regulatory constraint, branch agreement, firm agreement, and other. The merger of these two databases results in an unbalanced sample of 7,441 observations, corresponding to 1,545 companies, over the period 19912008. To our knowledge, this individual company database is unique for allowing an empirical analysis concerning the impact of these rigidities on TFP. As in Hübler and Jirjahn (2003), our evidence of good labour relations lies in the existence of binding collective agreements, at the firm or at the industry level. In France, the ability to conclude a collective agreement is a clear sign of good labour relations, between employers and at least some unions. Hence, even if it is declared as an obstacle to increase the capital operating time, the existence of a collective agreement (at the branch or the firm level) remains an appropriate proxy for good labour relations.

The empirical strategy consists in estimating a relation where firm-level TFP is explained by output changes, wages per employee, year, sector-year and firm-specific fixed effects along with different obstacles declared by firms, these obstacles being considered individually or interacted for some of them. These estimates may face a double causality bias: firms benefitting from high TFP may be able to provide higher wages. Employers could therefore overcome worker or union opposition, better secure supply, attract talents and negotiate more favourable firm agreements by being able to provide more generous compensations for increased flexibility. In order to address this bias, we implemented an instrumentation strategy based on Blundell and Bond (1998) using lagged obstacles levels and changes as instruments. We did also control for wages.

Our main results may be summarised as follows: i) 'workforce or union opposition' interacted with 'regulatory constraints' has a negative significant impact on total factor productivity (TFP). Regulatory constraints would become really binding when workers or unions use them as a tool to oppose management's decisions; ii) 'regulatory constraints' interacted with 'branch or firm agreement' has a positive significant impact on TFP. These agreements, which can only be obtained if labour relations are supportive, would be used by firms to offset the negative impact of regulatory constraints.

These results support the importance of labour relations quality, at the branch or the firm levels, as a powerful factor of productive performance. They provide an original confirmation to early insights in the literature (e.g. Freeman and Lazear, 1994). 
Section 2 presents the data. Section 3 details the empirical strategy and section 4 comments on the results. Section 5 displays the outcome of several robustness checks and section 6 concludes.

\section{Data and obstacles to increase capital operating time}

\subsection{An original dataset}

Our empirical analysis merges two firm-level annual datasets constructed by the Banque de France: FiBEn and a survey on factor utilisation degrees (FUD).

FiBEn is a large database built on fiscal documents, including balance sheets and profit-and-loss statements. It features all French firms with sales exceeding $€ 750,000$ per year, or with a credit outstanding higher than $€ 380,000$. Every year, these accounting data are available for about 200,000 firms. In 2004, FiBEn was covering $80 \%$ of the firms with 20 to 500 employees, and $98 \%$ of those employing more than 500 employees. This database allows calculating firm-level value added $(Q)$, the capital stock $(K)$, the volume of employment $(L)$ and computing total factor productivity $(T F P)$ :

- The value added volume $(Q)$ is calculated by dividing value added in value (production in value minus intermediate consumptions) by a national accounting index of value added price at the industry level (two digit decomposition level).

- The volume of capital $(K)$ sums gross capital volumes for buildings and equipment. Gross capital at historical price (as reported in tax statements) is divided by a national index for investment price, lagged with the mean age of gross capital (itself calculated from the share of depreciated capital in gross capital, at historical price). This measure corresponds to the volume of capital, usually by the end of a fiscal year. For this reason, we introduce a one-year lag for capital to compute share-weighted factor growth.

- The average employment level $(L)$ is directly available in FiBEn.

- Total factor productivity for firm $i$ in sector $j$ at date $t\left(T F P_{i j t}\right)$ is obtained by dividing total value added $Q_{i j t}$ by the volume of production inputs $V_{i j t}$, where:

$$
V_{i j t}=K_{i j t-1}^{1-\alpha_{j}} L_{i j t}{ }^{\alpha_{j}}
$$

with $\alpha_{j}$ the labour share in revenue for sector $j$, calculated from the median over firms in this industry, on the dataset period.

The FUD survey has been carried out each September since $1989^{1} .1,500$ to 2,500 plants $^{2}$ are covered by this survey, depending on the year. This dataset directly provides for each plant the annual growth rate of capital workweek $(W K)$ and the level of labour workweek $(W L)$.

While the FUD survey is carried out at the plant level, FiBEn gives information at the firm level. A difficulty in the data merge lies in the fact that some firms are multi plants. When several plants of a single firm were covered by the FUD survey, we aggregated for each year all plants of this firm, weighting them by their share in the firm's total employment. We considered the FUD survey answers to be representative enough when the employment level corresponding to this aggregation was higher than $50 \%$ of the one reported in FiBEn (otherwise, the firm was dropped from the final dataset ${ }^{3}$ ). Each

\footnotetext{
${ }^{1} 2002$ is unfortunately not present in the dataset since accidentally, paper questionnaires for the 2002 survey are no longer available at Banque de France.

${ }^{2}$ These plants are the ones usually covered by the Banque de France monthly survey on business climate.

${ }^{3}$ In the final dataset, only 55 observations correspond to multi-plants firms.
} 
time one observation was missing for a given firm, we interpolated its value taking the average of its one-period past and one-period next observations.

The sample used in this paper is an unbalanced firm panel of 7,441 observations, corresponding to 1,545 companies, over the period 1991-2008. The criteria underlying this sample selection are detailed below.

\subsection{Obstacles to shifts in capital operating time}

Our dataset not only provides rich insights about firm-level factor utilisation, but also a unique appraisal of rigidities faced by firms in increasing their capital workweek. Firms were directly asked to declare the presence of such rigidities and to characterize their legal, social or technical nature. More precisely, entrepreneurs answered the following question: "If you had to increase your capital operating time, and if your sales potential could justify it, would you meet obstacles or brakes such as...?»:

1- Worker opposition (WOPP)

2- Union opposition $(U O P P)$

3- Absence of qualified workforce $(A B S)$

4- Bottleneck on commodities or supply (BOTT)

5- Technical obstacles (TOBS)

6- Legal or regulatory constraint $(R E G)$

7- Branch agreement $(B R A)$

8- Firm agreement $(F I R)$

9- Other

Beyond reporting obstacles, firms were also asked to rank them. Given the potential heterogeneity in the firms' understanding of this ranking exercise, we preferred to particularly focus on the presence of an obstacle and made some methodological choices: in particular, some firms ranked systematically all obstacles, while some others selected just one, two or three obstacles. On the one hand, considering that an obstacle is present as soon as it is reported may be misleading, as some firms ranked all obstacles. On the other hand, considering only obstacles ranked in first position may rule out any possibility to analyse firms facing several rigidities. To deal with this "question understanding" potential bias, we choose to consider an obstacle as present if it is declared and ranked either in first, second or third position.

A strong correlation and possible confusion between different obstacles led us to adopt an aggregation procedure, so as to reduce some potential interpretation and multicollinearity biases. We first decided, in an arbitrary way, to aggregate $A B S, B O T T$ and $T O B S$ in a single variable named « Skills, supply or technical constraints $(T E C) »$, since the relevance of distinguishing these obstacles was weak in terms of policy implications. Then, we undertook a hierarchical clustering procedure, represented in Figure 1 , to further aggregate obstacles while keeping a strong explanatory power. 


\section{Figure 1: Hierarchical clustering procedure result}

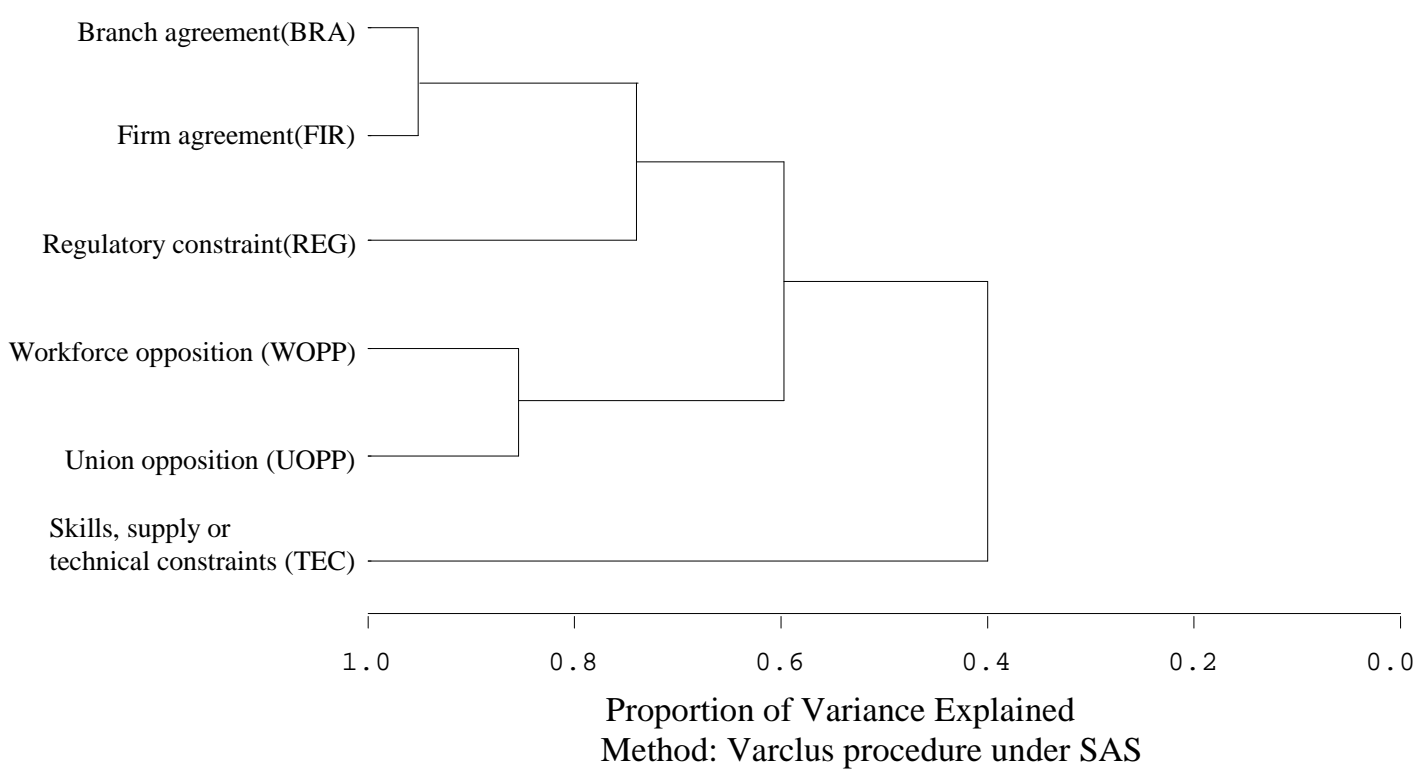

Figure 1 displays the way obstacles are aggregated through the clustering procedure. The horizontal axis represents the share of variance still explained after aggregating variables (taking as a benchmark the non-aggregated model). The first obstacles to be aggregated were branch and firm agreements, then workforce and union opposition. Not only these two aggregations seem intuitively relevant, they also allow explaining more than $80 \%$ of the variance associated with the non-aggregated model. We therefore decided to stop aggregating variables at this threshold, to avoid losing too much explanatory power with respect to the non-aggregated model. Table 1 summarizes the aggregation procedure outcome.

Table 1: Aggregation procedure

\begin{tabular}{|l|ll|}
\hline \multicolumn{1}{|c|}{ Aggregated obstacles $^{4}$... } & & ... from originally declared obstacles \\
\hline Workforce or union opposition (OPP) & - Workforce opposition (WOPP) \\
& - Union opposition (UOPP) \\
\hline Skills, supply or technical constraints (TEC) & - Absence of qualified workforce (ABS) \\
& - Bottleneck on commodities or supply (BOTT) \\
& - Technical obstacles (TOBS) \\
\hline Regulatory constraint (REG) & - Legal or regulatory constraint (REG) \\
\hline Branch or Firm Agreement (AGR) & - Branch agreement (BRA) \\
& - & Firm agreement (FIR) \\
\hline
\end{tabular}

Looking at the evolution of obstacle declarations through time yields interesting insights (Graph 1).

\footnotetext{
${ }^{4}$ For instance, the $O P P$ variable takes value 1 if workforce opposition (WOPP) and / or union opposition $(U O P P)$ are / is declared, 0 otherwise. Other aggregates were built the same way, from their corresponding components.
} 


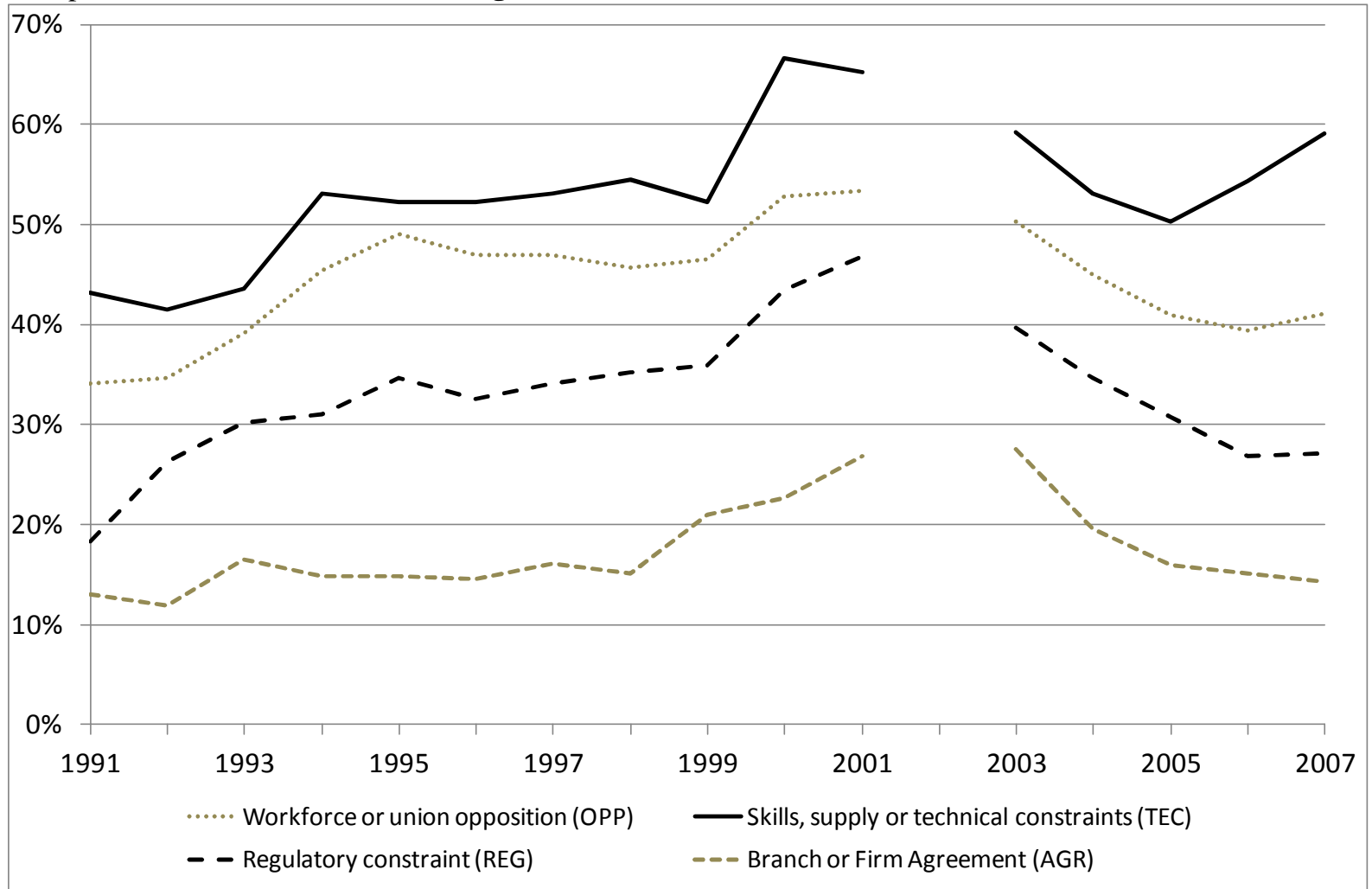

The panel is unbalanced, which may imply sample effects. 2002 is unfortunately not present in the dataset since accidentally, paper questionnaires for the 2002 survey are no longer available at the Banque de France.

First, it appears that the different obstacles can easily be ranked in terms of reporting frequency, this hierarchy being quite stable through time. Each year, between $40 \%$ and $70 \%$ of firms signalled the presence of skills, supply or technical constraints (TEC), which makes them the most frequently reported obstacles. Workforce or union oppositions $(O P P)$ were signalled by nearly $45 \%$ of firms every year, while regulatory obstacles were declared by a third of firms on average (with a peak at $47 \%$ in 2001). Obstacles linked to collective agreements at the branch or firm level (AGR) would be the least reported rigidities, but would nevertheless be faced by around 15\% of firms every year.

Second, aside from these hierarchical considerations, we observe a kind of common trend between obstacle reporting, stemming probably from the business cycle and its perception by firms. A global increase in obstacle declarations can be highlighted between 1998 and 2001. It is easily understandable that during expansions, firms perceive constraints in a stronger way, precisely because they feel the need to increase their production and, therefore, their capital operating time. As a matter of fact, the TEC obstacle showed the strongest cyclical component over 1991-2008.

Interestingly, the larger the firm, the more frequently obstacles are declared as regards workforce or union opposition $(O P P)$ and branch or firm agreements $(A G R)$ (see Graph 2). In contrast, the smaller the firm, the more frequently entrepreneurs report obstacles linked to skills, supply or technical constraints $(T E C)$ and regulatory constraints $(R E G)$. This tends to show that large firms have developed means to adapt technical shortages and regulatory obstacles, but would suffer more than smaller firms from workers' oppositions. Small firms in France are generally operating in a less unionized environment than big firms. This may explain why their reporting of obstacles linked to workforce or union opposition, and branch or firm agreements, is lower with respect to larger firms. 


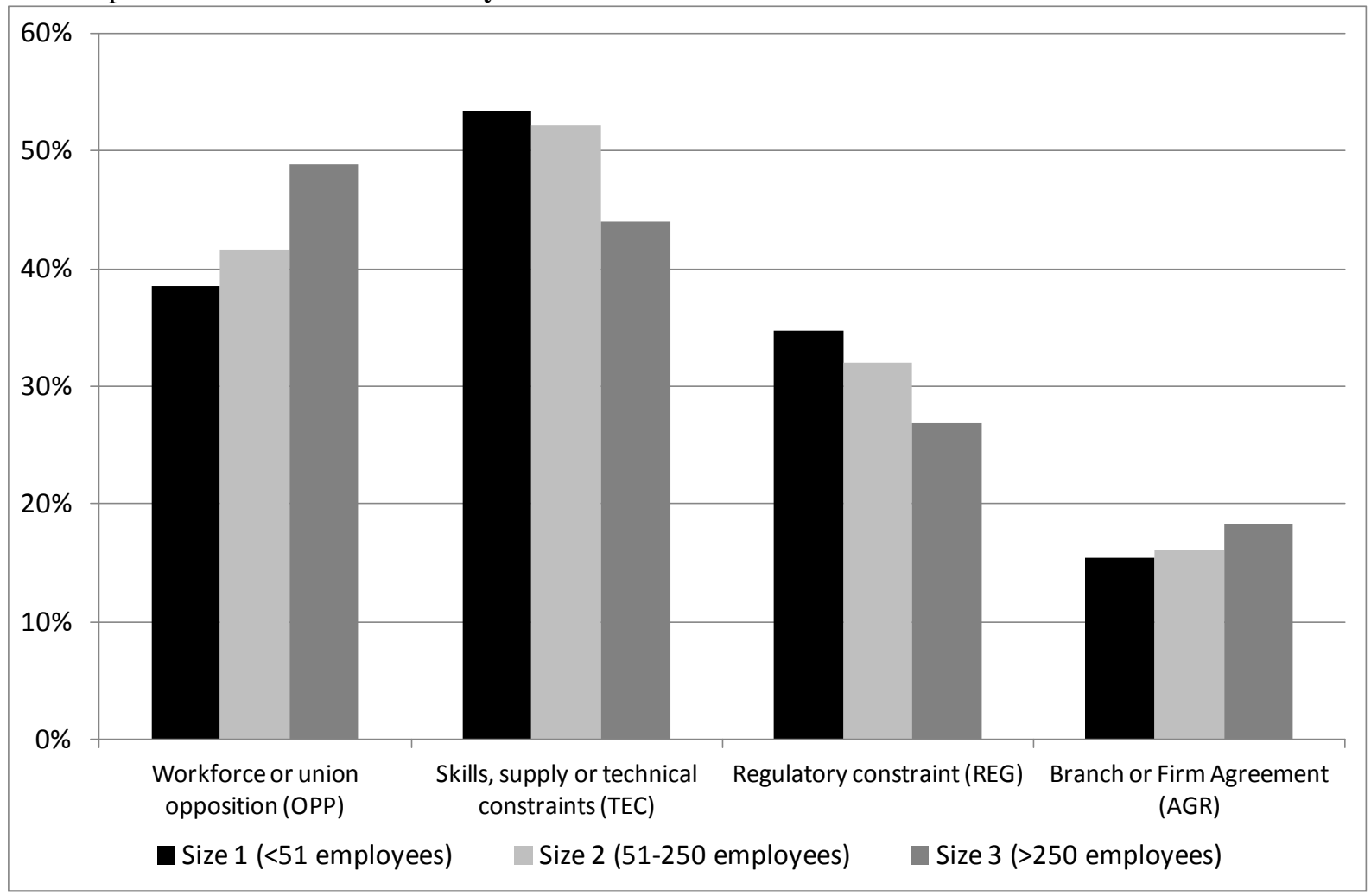

Further descriptive statistics about the variables used may be found in the appendix. We now explain and detail in the following section our empirical strategy.

\section{Empirical methodology}

In the FUD survey, obstacles to increase capital operating time provide some rich information on the constraints that may prevent total factor productivity $(T F P)$ improvements. In our estimations, these obstacles will therefore be used as TFP regressors, on the sub-sample of firms reporting at least one obstacle .

Skills, supply or technical constraints (TEC) bear on human capital and on capital utilisation in the upper phase of the cycle, which will impact our TFP measure. These shortages may constrain firms to adopt some sub-optimal production organisation or process, which could have an impact on TFP. Workforce or union opposition $(O P P)$ directly bears on TFP through a lower effort from the workers, or indirectly through a resistance to reorganisations of the production process. Regulatory constraints $(R E G)$ or branch/firm agreements $(A G R)$ may hinder TFP-improving reorganisations. On the other hand, $A G R$ testifies of a significant worker involvement, alleviating information asymmetries between employees and management and reducing economic inefficiencies (Freeman and Lazear, 1995), and more globally of good labour relations quality, which can have a positive productivity impact. Indeed, unionization (Brown and Medoff, 1978) or worker voices (Fairris and Askenazy, 2010) have been shown to have a positive impact on firm productivity.

\footnotetext{
${ }^{5}$ There may be a bias in using this sub-sample as firms reporting obstacles need to increase capital operating time and hence may be in a tense production phase. To deal with this potential issue, we control for the firmspecific production cycles through its value added growth as an explanatory variable, and for the firm structural situation through firm fixed effects. The whole sample cannot be used since firms that report no obstacle may do so because they do not need to increase their capital operating time, not because they do not face any obstacle.
} 
Some interactions between obstacles may be relevant. Indeed, workforce or union opposition may be more detrimental to TFP if this opposition can use regulatory constraints to prevent reorganisations of the production process $\left(O P P^{*} R E G\right)$. On the contrary, firm or branch agreements may have an ambiguous role, either acting as a kind of regulatory constraint in interaction with workers' opposition, or alleviating the degree of workforce opposition $\left(O P P^{*} A G R\right)$ and helping overcome rigidities stemming from regulation $\left(R E G^{*} A G R\right)$.

The estimated equation is the following:

$$
t f p_{i, t}=\alpha_{0}+\alpha_{1} \Delta q_{i, t}+\alpha_{2} w_{i, t}+\sum_{k=1}^{k=4} \beta_{k} O B S_{k, i, t-1}+\gamma X_{j, t}+\delta_{i}+\varepsilon_{i, t}
$$

with variables:

- $t f p$ : total factor productivity (in $\log$ )

- $q$ : value added (in $\log$ )

- $w$ : wages per employee (in log)

- $O B S_{\mathrm{k}}$ : obstacles to increasing capital operating time

- $X$ : a vector of controls including sector-year dummies

- $\delta$ : firm fixed effects

- $\varepsilon$ : error term

and subscripts:

- $\quad i$ for firm

- $j$ for industry

- $t$ for year

We use sector-year dummies to control for industry cycles and TFP trends ${ }^{6}$. Value added growth controls for potential mismeasurements of factor utilisation in the TFP regression (cf. Cette et al., 2011), firm-specific cycles or activity trends. Wages per employee control for the unmeasured quality of human capital, but also for the favourable impact of a generous wage policy on labour climate. We also use firm-specific fixed effects, which control for time-invariant firm unobserved heterogeneity such as management quality.

We may face a double causality bias: firms benefitting from high TFP may be able to provide higher wages, overcoming worker or union opposition, to better secure supply, attract talents and negotiate more favourable firm agreements by being able to provide more generous compensations for increased flexibility. In order to address this bias, we implement an instrumentation strategy based on Blundell and Bond (1998) using lagged obstacles levels and changes as instruments. Changes in value added may be endogenous and are also instrumented the same way. As we may face heteroscedasticity and serial correlation, we use the generalised method of moments with robust standard errors.

\section{Results}

The main estimates are presented in Table 2. It is noteworthy to emphasise that OLS results are consistent with 2SLS ones in terms of sign if not significance.

'Value added growth' has a positive and significant impact on the TFP level, with stable coefficients, around 0.28 for 2SLS estimates (columns 2 and 4). This result, usually found in empirical

\footnotetext{
6 With an upward-trending TFP regressed on obstacles taking values 0 or 1 , year dummies are needed to avoid estimating a spurious relationship.
} 
studies, indicates the existence of short-term increasing returns to production factors. Cette et al. (2011) argue they can be due to omitted variables, particularly the intensity of factor utilisation. With the very same data set, they show how increasing returns to scale disappear when working time, capacity utilisation rate and mainly capital operating time are introduced in the production function.

'Wages per employee' has a positive and significant impact on the TFP level, with quite stable coefficients, around 0.26 for 2SLS estimates (columns 2 and 4), which is consistent with the literature. 'Skills, supply or technological constraints' have no significant impact on the TFP level, which may not be surprising. Shortages may constrain firms to adopt a non-optimal production organisation or process, which could decrease or increase, depending on the situation, the TFP level compared to a situation without such shortages. For example, a shortage in labour or capital may lead to a more intensive use of the available quantity of these two factors, and increase TFP. Moreover, as this obstacle is reported by many firms throughout the period (cf. Graph 1), its impact may be captured by firm fixed effects as it may reflect the usual recruitment policy or supply management of the firm.

Without taking into account the potential interactions between explanatory variables (columns 1 and 2 ), 'workforce or union opposition' is the only obstacle which would have a significant impact on productivity. The existence of such an opposition would decrease TFP by around 2\% (column 2). 'Regulatory constraints' do not have a significantly negative direct impact on productivity. Nonetheless, it appears (columns 3 and 4 ) that these regulatory constraints do have a negative impact on TFP when 'workforce or union opposition' are reported, leading to a $-2 \%$ decrease in TFP on average (column 4). This suggests that 'regulatory constraints' would only become significantly binding when workers or unions use them as a tool to oppose management decisions. For example, working time rules are complex and workers or unions, through the threat of legal procedure, may lead to a stricter application of these rules in cases of deteriorated labour relations.

Besides, 'branch or firm agreement' has no direct impact on TFP (columns 1 to 4) but the interaction between 'branch and firm agreement' and 'regulatory constraints' has a positive and significant impact (columns 3 and 4). These puzzling results can receive two explanations. First, a branch or firm collective agreement can organize efficient working organisations, thus alleviating regulatory constraints. Secondly, the French labour code allows softening specified regulatory constraints through a collective agreement. This was emphasised in the context of the 35-hour workweek policy implemented in France from 1998, after the left-wing electoral victory of $1997^{7}$. This policy consisted in a decrease from 39 to 35 hours, in 2000 for firms of more than 20 employees (which represent more than $97 \%$ of our sample) and in 2002 for other firms, of the legal weekly working time threshold from which firms have to pay an overtime wage premium. For a firm decreasing to 35 hours or less the usual weekly working time of its employees, it was possible to get generous financial subsidies from the State if this decrease was organised through a collective agreement between social partners, at the firm level for firms of more than 50 employees and also possibly at the branch level for other firms. To get these subsidies, the agreements had to be signed by unions representing at least $50 \%$ of the employee votes at union elections. But the 35 hour workweek laws allowed firms to implement through a collective agreement some flexible labour organisation with a possible positive impact on TFP. For instance, it was possible through agreements to exclude some breaks of the accounted working time, or to account daily rather than hourly the working time for white collars, or to respect the 35 hours threshold in average over the year or even in average over several years. But the use of these disposals needed good quality labour relations, employee unions having the choice not to allow it. The results also indicate that 'branch or firm agreement' would have offset the significant negative impact of the interaction between 'regulatory constraints' and 'work force or union opposition', as it yields a positive impact of $4 \%$ on TFP. The interaction between 'branch or firm agreement' and 'work force or union opposition' is not significant when instrumented: indeed, 'branch or firm agreement' may actually be alleviating 'work force or union opposition' and hence neutralising its impact.

7 The 35-hour workweek policy change is captured in our analysis by the year fixed-effect. 
Table 3 displays estimates where branch and firm agreements are separated. It is difficult to identify separately both types of agreements which are highly correlated but it appears that the positive interacted impact of 'agreements' with 'regulatory constraints' would result mostly from 'firm agreements' rather than 'branch agreements' (table 3, column 6). This result indicates that it is mainly at the firm level that good quality labour relations can allow to use some complex regulation disposals to improve the firm's productive performance.

These results support the role of labour relations quality, mainly at the firm level, as a powerful factor of productive performance. They provide an original confirmation to early insights in the literature (e.g. Freeman and Lazear, 1994).

\section{Robustness checks}

Our flagship result is the structural regression in Table 2, column 4, which emphasises the role of interactions between regulatory constraints, branch or firm agreements, and employee or union opposition. In Table 4, we present several robustness checks for this regression, on different subsamples:

- First, we exclude firms which TFP level lies in the first or last 5 percentiles. That way, we assess whether our results are driven by a small number of extreme observations. The coefficient signs are not altered, although their significance changes: $R E G * A G R$ is still significant, but $O P P * R E G$ is not.

- Then, we exclude one by one all sectors representing more than $5 \%$ of the sample, to evaluate the sensitivity of our results to specific activities (although we already had firm fixed effects and year-industry dummies in the reference equation). Significance and magnitude of the coefficients are barely altered, especially for $R E G^{*} A G R$. OPP * REG is however not significant for a large number of subsamples.

We provide in Table 5 further robustness estimates with different specifications:

- We remove year*sector dummies (column 1), while keeping year dummies which are necessary to avoid a spurious regression of a time series (TFP) on stationary variables. Our main results are not altered: $R E G * A G R$ and $O P P^{*} R E G$ keep the same signs significance and magnitude. The magnitude is stronger for $R E G^{*} A G R$, although less precise.

- We remove the firm production cycle control, $\triangle V A$. Indeed, this control may encompass a lot of relationships beyond the firm production cycle (in particular supply shocks due to our variables of interest). Coefficients in the reference equation are not altered in their signs or magnitude, but the $O P P^{*} R E G$ is no longer significant.

- We remove the control for wage per head, which may be collinear with labour relations. Coefficients are practically unaltered in signs or significance.

Our main result, showing that the negative effect of regulatory constraints on productivity can be alleviated by branch or firm agreements, appears to be fairly robust. However, the fact that regulatory constraints may be more stringent when employees or unions use them to prevent TFP improvements tends to be non-significant under some robustness checks, although the sign and magnitude of this effect is unaltered. 


\section{Conclusion}

Our aim was to analyse the impact on productivity of good labour relations. We have used an original database containing 7,441 observations, corresponding to 1,545 French companies, over 1991-2008. To our knowledge, this company-level database is unique in allowing such an analysis. We assume the existence of a collective agreement (at the branch or the firm level) to be a proxy for good labour relations.

The main results from our empirical investigation are the following: $i$ ) 'workforce or union opposition' interacted with 'regulatory constraints' has a negative significant impact on total factor productivity (TFP). Regulatory constraints would become really binding when workers or unions use them as a tool to oppose management's decisions; ii) 'regulatory constraints' interacted with 'branch or firm agreement' has a positive significant impact on TFP. These agreements, which can only be obtained if labour relations are supportive, would be used by firms to offset the negative impact of regulatory constraints. These results support the importance of labour relations quality and provide an original confirmation to early insights in the literature.

Nevertheless, we must remain cautious in generalising these results, since France is a particular country concerning working relations. Among OECD countries, France has the lowest union membership rate. Related with that, France is probably the country (or at least one of the countries) where labour market regulation is the most stringent and where collective bargaining processes are the poorest and the weakest. Labour relations get conflictual more quickly, leading more easily to strikes for example, in France than in other countries. In such circumstances, the ability to conclude a collective agreement is probably a stronger indication for good labour relations in France than elsewhere. We cannot exclude that the impact of collective agreement, taken as a proxy of good labour relations, could have a positive but lower impact on productivity in other countries. Our result would need to be confirmed on a database covering other countries, for it to be generalised.

\section{Bibliography:}

ADDISON J. T. (2005). The determinants of firm performance: unions, works councils, and employee involvement/high-performance work practices. Scottish Journal of Political Economy, Vol. 52, No. 3, July.

ADDISON, J. T., SCHNABEL, C. and WAGNER, J. (2001). Works councils in Germany: their effects on establishment performance. Oxford Economic Papers, 53, pp. 659-94.

ADDISON J. T., SIEBERT S., WAGNER J. and XIANGDONG W. (2000). Worker Participation and Firm Performance: Evidence from Germany and Britain. British Journal of Industrial Relations, Blackwell Publishers Ltd/London School of Economics, vol. 38(1), pages 7-48, 03.

AGHION P., ALGAN Y. and CAHUC P. (2011). Civil society and the state: The interplay between cooperation and minimum wage regulation. Journal of the European Economic Association , 9(1), pp.3-42.

BLACK, S. and LYNCH, L. M. (2001). How to compete: the impact of workplace practices and information technology on productivity. Review of Economics and Statistics, 83, pp. 434-45.

BLUNDELL, R. and BOND, S. (1998). Initial conditions and moment restrictions in dynamic panel data models. Journal of Econometrics, 87, pp. 115-143.

BROWN, C. and MEDOFF, J. L. (1978).Trade unions in the production process. Journal of Political Economy, 86, pp. 355-78.

CETTE G., DROMEL N., LECAT R., and PARET A.-C. (2011). Production factor returns: the role of factor utilisation. Banque de France Working paper $n^{\circ} 317$. 
CLARK, K. B. (1984). Unionization and firm performance: the impact on profits, growth, and productivity. American Economic Review, 74, pp. 893-919.

COOKE, W. N. (1994). Employee participation programmes, group-based incentives, and company performance: a union-nonunion comparison. Industrial and Labor Relations Review, 47, pp. 594-609.

DEERY S.J. and IVERSON R.D., (2005). Labor-management cooperation: antecedents and impact on organisational performance. Industrial and Labor Relations Review, Vol. 58, No. 4 (July).

FAIRRIS, D. \& ASKENAZY, P. (2010). Works Councils and Firm Productivity in France. Journal of Labor Research, 31, pp. 209-229.

FREEMAN, R. B. and LAZEAR, E. P. (1995).An economic analysis of works councils. In J.Rogers and W. Streeck (eds.), Works Councils, Consultation, Representation and Cooperation in Industrial Relations. Chicago, IL: University of Chicago Press.

HIRSCH B. T. (2007), What Do Unions Do for Economic Performance?, in BENNET J. T. And KAUFMAN B. E. (eds), What Do Unions Do?, Transaction Publishers, pp. 193-237.

HÜBLER, O. and JIRJAHN, U. (2003). Works councils and collective bargaining in Germany: the impact on productivity and wages. Scottish Journal of Political Economy, 50, pp. 471-91.

ICHNIOWSKI C., (1986). The Effects of Grievance Activity on Productivity. Industrial and Labor Relations Review, Vol. 40, No. 1 (October), pp. 75-89.

KATZ H., KOCHAN T., KEEFE J. (1987). Industrial Relations and Productivity in the U.S. Automobile Industry. Brookings Papers On Economic Activity. 1987; 3:685-715.

KATZ H., KOCHAN T.A. and K.R. GOBEILLE, (1983). Industrial Relations Performance, Economic Performance, and QWL Programs: An Interplant Analysis. Industrial and Labor Relations Review, Vol. 37, No. 1 (October), pp. 3-17.

KLEINER M., LEONARD J.S. and A.M. PILARSKI (2002). How industrial relations affects plant performance: the case of commercial aircraft manufacturing. Industrial and Labor Relations Review, Vol. 55, No. 2 (January 2002)

MAS, A. (2008). Labor Unrest and the Quality of Production: Evidence from the Construction Equipment Resale Market. Review of Economic Studies 75(1): 229-258.

MORIKAWA, M. (2010). Labor unions and productivity: An empirical analysis using Japanese firmlevel data. Labour Economics, Elsevier, vol. 17(6), pages 1030-1037, December.

OCDE (2009), Measuring Entrepreneurship. 
Appendix

Descriptive Statistics

FiBEn \& FUD (Factor Utilisation Degrees) survey

\begin{tabular}{|c|c|c|c|c|c|c|c|c|c|}
\hline Variable & Description & Source & p10 & Q1 & Median & Q3 & P90 & Mean & $\begin{array}{c}\text { Standard } \\
\text { Error }\end{array}$ \\
\hline$O P P$ & $\begin{array}{l}\text { Worker or union } \\
\text { opposition }\end{array}$ & FUD survey & 0 & 0 & 0 & 1 & 1 & 0,43 & 0,49 \\
\hline$T E C$ & $\begin{array}{l}\text { Skills, supply or } \\
\text { technical } \\
\text { constraints }\end{array}$ & FUD survey & 0 & 0 & 1 & 1 & 1 & 0,50 & 0,50 \\
\hline$R E G$ & $\begin{array}{l}\text { Regulatory } \\
\text { constraints } \\
\end{array}$ & FUD survey & 0 & 0 & 0 & 1 & 1 & 0,31 & 0,46 \\
\hline$A G R$ & $\begin{array}{l}\text { Branch or firm } \\
\text { agreement }\end{array}$ & FUD survey & 0 & 0 & 0 & 0 & 1 & 0,16 & 0,37 \\
\hline$B R A$ & $\begin{array}{l}\text { Branch } \\
\text { agreement }\end{array}$ & FUD survey & 0 & 0 & 0 & 0 & 1 & 0,12 & 0,33 \\
\hline FIR & Firm agreement & FUD survey & 0 & 0 & 0 & 0 & 1 & 0,13 & 0,33 \\
\hline$O P P \times R E G$ & & FUD survey & 0 & 0 & 0 & 0 & 1 & 0,20 & 0,40 \\
\hline OPP $\times A G R$ & & FUD survey & 0 & 0 & 0 & 0 & 1 & 0,13 & 0,33 \\
\hline$O P P x B R A$ & & FUD survey & 0 & 0 & 0 & 0 & 0 & 0,10 & 0,30 \\
\hline OPP $\times$ FIR & & FUD survey & 0 & 0 & 0 & 0 & 1 & 0,11 & 0,31 \\
\hline$R E G \times A G R$ & & FUD survey & 0 & 0 & 0 & 0 & 1 & 0,12 & 0,32 \\
\hline REG $x$ BRA & & FUD survey & 0 & 0 & 0 & 0 & 1 & 0,10 & 0,30 \\
\hline REG $x$ FIR & & FUD survey & 0 & 0 & 0 & 0 & 0 & 0,09 & 0,28 \\
\hline TFP & $\begin{array}{l}\text { Total factor } \\
\text { productivity in } \\
\log \end{array}$ & FiBEn & 2,43 & 2,62 & 2,84 & 3,10 & 3,38 & 2,87 & 0,40 \\
\hline$\Delta \mathbf{q}$ & $\begin{array}{l}1^{\text {st }} \text { difference } \\
\text { value added in } \\
\log \end{array}$ & FiBEn & $-0,17$ & $-0,06$ & 0,02 & 0,11 & 0,21 & 0,02 & 0,20 \\
\hline $\mathbf{w}$ & $\begin{array}{l}\text { Labour cost per } \\
\text { employee in log }\end{array}$ & FiBEn & 3,13 & 3,30 & 3,47 & 3,64 & 3,80 & 3,46 & 0,28 \\
\hline
\end{tabular}




\begin{tabular}{|l|l|c|}
\hline Industry (control variables) & Agriculture and food industry (AFI) & Frequency \\
B0 & Clothing, leather and footwear & 10.1 \\
C1 & Paper, printing and publishing & 5.7 \\
C2 & Chemical, rubber, plastics and fuel & 7.0 \\
C3 & Household equipment industries & 1.7 \\
C4 & Industry & 5.4 \\
D0 & Shipbuilding, aeronautic and railway industries & 2.2 \\
E1 & Mechanical equipment industries & 1.5 \\
E2 & Electric and electronic equipment industries & 14.5 \\
E3 & Mineral products industry & 3.4 \\
F1 & Textile industry & 3.8 \\
F2 & Wood and paper industry & \\
F3 & Chemicals and plastics industry & \\
F4 & Metallurgy and metal transformation & \\
F5 & Electric and electronic components industry & \\
F6 & & 20.7 \\
& & 3.3 \\
\end{tabular}




\begin{tabular}{|c|c|c|c|c|}
\hline & $\begin{array}{c}(1) \\
\text { Without } \\
\text { interactions }\end{array}$ & $\begin{array}{c}(2) \\
\text { Without } \\
\text { interactions - } \\
\text { 2SLS }\end{array}$ & $\begin{array}{c}(3) \\
\text { With } \\
\text { interactions }\end{array}$ & $\begin{array}{c}(4) \\
\text { With } \\
\text { interactions - } \\
\text { 2SLS }\end{array}$ \\
\hline$\Delta$. Value added $(\log )$ & $\begin{array}{l}0.526^{* * * *} \\
(0.00970)\end{array}$ & $\begin{array}{l}0.285^{* * * *} \\
(0.0226)\end{array}$ & $\begin{array}{l}0.527^{* * * *} \\
(0.00970)\end{array}$ & $\begin{array}{l}0.279^{* * * *} \\
(0.0229)\end{array}$ \\
\hline Wage per head $(\log )$ & $\begin{array}{l}0.224^{* * *} \\
(0.0147)\end{array}$ & $\begin{array}{l}0.263^{* * *} \\
(0.0326)\end{array}$ & $\begin{array}{l}0.225^{* * *} \\
(0.0147)\end{array}$ & $\begin{array}{l}0.259^{* * *} \\
(0.0328)\end{array}$ \\
\hline Worforce or union opposition $\left(\mathrm{OPP}_{-1}\right)$ & $\begin{array}{l}-0.0091^{*} \\
(0.0048)\end{array}$ & $\begin{array}{l}-0.0217^{* *} \\
(0.0092)\end{array}$ & $\begin{array}{l}-0.00150 \\
(0.0060)\end{array}$ & $\begin{array}{l}0.00377 \\
(0.0080)\end{array}$ \\
\hline $\begin{array}{l}\text { Skills, supply or technical constraints } \\
\left(\mathrm{TEC}_{-1}\right)\end{array}$ & $\begin{array}{c}0.0058 \\
(0.0045)\end{array}$ & $\begin{array}{c}0.0198 \\
(0.0286)\end{array}$ & $\begin{array}{l}0.00438 \\
(0.0045)\end{array}$ & $\begin{array}{l}-0.0058 \\
(0.0074)\end{array}$ \\
\hline Regulatory constraints $\left(\mathrm{REG}_{-1}\right)$ & $\begin{array}{c}0.0059 \\
(0.0049)\end{array}$ & $\begin{array}{l}0.00858 \\
(0.0082)\end{array}$ & $\begin{array}{c}0.0070 \\
(0.0073)\end{array}$ & $\begin{array}{c}0.0119 \\
(0.0106)\end{array}$ \\
\hline Branch or firm agreement $\left(\mathrm{AGR}_{-1}\right)$ & $\begin{array}{l}-0.0091 \\
(0.00585)\end{array}$ & $\begin{array}{l}-0.0105 \\
(0.0104)\end{array}$ & $\begin{array}{l}-0.0067 \\
(0.0132)\end{array}$ & $\begin{array}{l}-0.0494 \\
(0.0323)\end{array}$ \\
\hline $\begin{array}{l}\text { Worforce or union opposition and } \\
\text { regulatory constraints }\left(\mathrm{OPP}_{-1} \mathrm{X} \mathrm{REG}_{-1}\right)\end{array}$ & & & $\begin{array}{r}-0.00994 \\
(0.0095)\end{array}$ & $\begin{array}{l}-0.0208^{*} \\
(0.0122)\end{array}$ \\
\hline $\begin{array}{l}\text { Worforce or union opposition and branch } \\
\text { or firm agreement }\left(\mathrm{OPP}_{-1} \mathrm{X} \mathrm{AGR}_{-1}\right)\end{array}$ & & & $\begin{array}{l}-0.0216^{*} \\
(0.0128)\end{array}$ & $\begin{array}{c}0.0096 \\
(0.0238)\end{array}$ \\
\hline $\begin{array}{l}\text { Regulatory constraints and branch or firm } \\
\text { agreement } \\
\left(\mathrm{REG}_{-1} \mathrm{X} \mathrm{AGR}_{-1}\right)\end{array}$ & & & $\begin{array}{l}0.0217^{*} \\
(0.0120)\end{array}$ & $\begin{array}{l}0.0420^{* *} \\
(0.0208)\end{array}$ \\
\hline $\mathrm{N}^{\circ}$ Observations & 7,441 & 7,441 & 7,441 & 7,441 \\
\hline Adj. $R^{2}$ & 0.222 & 0.226 & 0.222 & 0.221 \\
\hline Sargan-Hansen & & 14.90 & & 6.031 \\
\hline Sargan-Hansen p-value & & 0.313 & & 0.420 \\
\hline
\end{tabular}

Robust standard errors in parentheses

${ }^{*} p<0.1,{ }^{* *} p<0.05,{ }^{* * *} p<0.01$

Firm fixed effects, two stage least square estimates when specified, generalized method of moments. Lagged levels and lagged difference of obstacles used as instruments. Year, Sector X Year dummies and constant included but not reported. 
Table 3 - Separating branch and firm agreements

\begin{tabular}{|c|c|c|c|c|}
\hline & $\begin{array}{c}\text { (1) } \\
\text { Without } \\
\text { interactions }\end{array}$ & $\begin{array}{c}(2) \\
\text { Without } \\
\text { interactions - } \\
\text { 2SLS }\end{array}$ & $\begin{array}{c}(3) \\
\text { With } \\
\text { interactions }\end{array}$ & $\begin{array}{c}(4) \\
\text { With } \\
\text { interactions - } \\
\text { 2SLS }\end{array}$ \\
\hline$\Delta$. Value added $(\log )$ & $\begin{array}{l}0.526^{* \cdots *} \\
(0.00970)\end{array}$ & $\begin{array}{l}0.284^{* * * *} \\
(0.0226)\end{array}$ & $\begin{array}{l}0.527^{* * *} \\
(0.00971)\end{array}$ & $\begin{array}{l}0.283^{\text {**** }} \\
(0.0227)\end{array}$ \\
\hline Wage per head $(\log )$ & $\begin{array}{l}0.225^{\text {**** }} \\
(0.0147)\end{array}$ & $\begin{array}{l}0.263^{\text {**** }} \\
(0.0326)\end{array}$ & $\begin{array}{l}0.225^{* * *} \\
(0.0147)\end{array}$ & $\begin{array}{l}0.262^{* * *} \\
(0.0328)\end{array}$ \\
\hline Worforce or union opposition $\left(\mathrm{OPP}_{-1}\right)$ & $\begin{array}{l}-0.00934^{*} \\
(0.00487)\end{array}$ & $\begin{array}{l}-0.0240^{* *} \\
(0.00964)\end{array}$ & $\begin{array}{c}-0.00204 \\
(0.00602)\end{array}$ & $\begin{array}{c}0.00440 \\
(0.00777)\end{array}$ \\
\hline $\begin{array}{l}\text { Skills, supply or technical constraints } \\
\left(\text { TEC }_{-1}\right)\end{array}$ & $\begin{array}{c}0.00620 \\
(0.00451)\end{array}$ & $\begin{array}{c}0.0270 \\
(0.0343)\end{array}$ & $\begin{array}{c}0.00463 \\
(0.00461)\end{array}$ & $\begin{array}{l}-0.00691 \\
(0.00758)\end{array}$ \\
\hline Regulatory constraints $\left(\mathrm{REG}_{-1}\right)$ & $\begin{array}{c}0.00644 \\
(0.00503)\end{array}$ & $\begin{array}{c}0.00921 \\
(0.00855)\end{array}$ & $\begin{array}{c}0.00850 \\
(0.00729)\end{array}$ & $\begin{array}{c}0.0141 \\
(0.0104)\end{array}$ \\
\hline Branch agreement $\left(\mathrm{BRA}_{-1}\right)$ & $\begin{array}{c}-0.0103 \\
(0.00794)\end{array}$ & $\begin{array}{l}-0.0146 \\
(0.0106)\end{array}$ & $\begin{array}{l}-0.0131 \\
(0.0198)\end{array}$ & $\begin{array}{l}-0.0257 \\
(0.0571)\end{array}$ \\
\hline Firm agreement $\left(\right.$ FIR $\left._{-1}\right)$ & $\begin{array}{l}-0.000200 \\
(0.00769)\end{array}$ & $\begin{array}{l}0.00118 \\
(0.0100)\end{array}$ & $\begin{array}{l}0.00927 \\
(0.0167)\end{array}$ & $\begin{array}{l}-0.0564 \\
(0.0403)\end{array}$ \\
\hline $\mathrm{OPP}_{-1} \mathrm{X} \mathrm{REG}_{-1}$ & & & $\begin{array}{c}-0.0114 \\
(0.00981)\end{array}$ & $\begin{array}{l}-0.0232^{*} \\
(0.0138)\end{array}$ \\
\hline $\mathrm{OPP}_{-1} \mathrm{X} \mathrm{BRA}_{-1}$ & & & $\begin{array}{l}-0.0108 \\
(0.0171)\end{array}$ & $\begin{array}{l}-0.00640 \\
(0.0329)\end{array}$ \\
\hline $\mathrm{OPP}_{-1} \mathrm{X} \mathrm{FIR}_{-1}$ & & & $\begin{array}{l}-0.0263 \\
(0.0177)\end{array}$ & $\begin{array}{c}0.0317 \\
(0.0348)\end{array}$ \\
\hline $\mathrm{REG}_{-1} \mathrm{X} \mathrm{BRA}_{-1}$ & & & $\begin{array}{c}0.0103 \\
(0.0185)\end{array}$ & $\begin{array}{c}0.0143 \\
(0.0417)\end{array}$ \\
\hline $\mathrm{REG}_{-1} \mathrm{X} \mathrm{FIR}_{-1}$ & & & $\begin{array}{c}0.0245 \\
(0.0162)\end{array}$ & $\begin{array}{l}0.0465^{* *} \\
(0.0200)\end{array}$ \\
\hline $\mathrm{N}^{\circ}$ Observations & 7,441 & 7,441 & 7,441 & 7,441 \\
\hline Adj. $R^{2}$ & 0.222 & 0.224 & 0.222 & 0.223 \\
\hline Sargan-Hansen & & 14.05 & & 11.69 \\
\hline Sargan-Hansen p-value & & 0.297 & & 0.232 \\
\hline
\end{tabular}

Robust standard errors in parentheses; ${ }^{*} p<0.1,{ }^{* * *} p<0.05,{ }^{* * * *} p<0.01$

Firm fixed effects, two stage least square estimates when specified, generalized method of moments. Lagged levels and lagged difference of obstacles used as instruments. Year, Sector X Year dummies and constant included but not reported. 
Table 4 - Robustness to exclusion of specific observations

\begin{tabular}{|c|c|c|c|c|c|c|c|c|c|c|}
\hline Exclusion of.. & $\begin{array}{c}\text { (1) } \\
\text { Reference } \\
\text { equation }\end{array}$ & $\begin{array}{c}(2) \\
\text { First and } \\
\text { last } 5 \\
\text { percentiles }\end{array}$ & $\begin{array}{c}(3) \\
\text { Food } \\
\text { products }\end{array}$ & $\begin{array}{l}\text { (4) } \\
\text { Textile }\end{array}$ & $\begin{array}{r}\text { (5) } \\
\text { Printing }\end{array}$ & $\begin{array}{l}\quad(6) \\
\text { Households } \\
\text { equipment }\end{array}$ & $\begin{array}{c}\text { (7) } \\
\text { Mecanical } \\
\text { equipments }\end{array}$ & $\begin{array}{l}(8) \\
\text { Wood }\end{array}$ & $\begin{array}{c}(9) \\
\text { chemicals }\end{array}$ & $\begin{array}{l}\quad(10) \\
\text { metal } \\
\text { products }\end{array}$ \\
\hline $\begin{array}{l}\Delta . \text { Value added } \\
(\log )\end{array}$ & $\begin{array}{l}0.279^{* * *} \\
(0.0229)\end{array}$ & $\begin{array}{l}0.195^{* * * *} \\
(0.0170)\end{array}$ & $\begin{array}{l}0.295^{* * *} \\
(0.0130)\end{array}$ & $\begin{array}{l}0.274^{* * * *} \\
(0.0129)\end{array}$ & $\begin{array}{l}0.272^{* * *} \\
(0.0129)\end{array}$ & $\begin{array}{l}0.276^{* * * *} \\
(0.0129)\end{array}$ & $\begin{array}{l}0.281^{* * * *} \\
(0.0138)\end{array}$ & $\begin{array}{l}0.278^{* * *} \\
(0.0131)\end{array}$ & $\begin{array}{l}0.272^{* * * *} \\
(0.0129)\end{array}$ & $\begin{array}{l}0.282^{* * * *} \\
(0.0143)\end{array}$ \\
\hline $\begin{array}{l}\text { Wage per head } \\
(\log )\end{array}$ & $\begin{array}{l}0.259^{* * * *} \\
(0.0328)\end{array}$ & $\begin{array}{l}0.245^{* * *} \\
(0.0334)\end{array}$ & $\begin{array}{l}0.261^{* * *} \\
(0.0162)\end{array}$ & $\begin{array}{l}0.261^{* * *} \\
(0.0160)\end{array}$ & $\begin{array}{l}0.260^{* * *} \\
(0.0157)\end{array}$ & $\begin{array}{l}0.284^{* * *} \\
(0.0163)\end{array}$ & $\begin{array}{l}0.269^{* * *} \\
(0.0168)\end{array}$ & $\begin{array}{l}0.257^{* * *} \\
(0.0159)\end{array}$ & $\begin{array}{l}0.263^{* * *} \\
(0.0155)\end{array}$ & $\begin{array}{l}0.243^{* * *} \\
(0.0169)\end{array}$ \\
\hline $\mathrm{OPP}_{-1}$ & $\begin{array}{c}0.00377 \\
(0.00803)\end{array}$ & $\begin{array}{l}-0.000475 \\
(0.00754)\end{array}$ & $\begin{array}{c}0.00216 \\
(0.00842)\end{array}$ & $\begin{array}{c}0.00475 \\
(0.00844)\end{array}$ & $\begin{array}{c}0.00273 \\
(0.00845)\end{array}$ & $\begin{array}{c}0.00288 \\
(0.00841)\end{array}$ & $\begin{array}{c}0.00710 \\
(0.00875)\end{array}$ & $\begin{array}{c}0.00608 \\
(0.00869)\end{array}$ & $\begin{array}{c}0.00366 \\
(0.00837)\end{array}$ & $\begin{array}{l}-0.00161 \\
(0.00919)\end{array}$ \\
\hline $\mathrm{TEC}_{-1}$ & $\begin{array}{l}-0.00576 \\
(0.00737)\end{array}$ & $\begin{array}{c}0.00429 \\
(0.00483)\end{array}$ & $\begin{array}{l}-0.00874 \\
(0.00785)\end{array}$ & $\begin{array}{l}-0.00522 \\
(0.00779)\end{array}$ & $\begin{array}{l}-0.00425 \\
(0.00793)\end{array}$ & $\begin{array}{l}-0.00685 \\
(0.00790)\end{array}$ & $\begin{array}{l}-0.00705 \\
(0.00824)\end{array}$ & $\begin{array}{l}-0.00436 \\
(0.00802)\end{array}$ & $\begin{array}{l}-0.00306 \\
(0.00784)\end{array}$ & $\begin{array}{l}-0.00420 \\
(0.00876)\end{array}$ \\
\hline $\mathrm{REG}_{-1}$ & $\begin{array}{c}0.0119 \\
(0.0106)\end{array}$ & $\begin{array}{c}0.00402 \\
(0.00964)\end{array}$ & $\begin{array}{l}0.00974 \\
(0.0106)\end{array}$ & $\begin{array}{c}0.0106 \\
(0.0106)\end{array}$ & $\begin{array}{c}0.0149 \\
(0.0107)\end{array}$ & $\begin{array}{c}0.0118 \\
(0.0106)\end{array}$ & $\begin{array}{l}0.00570 \\
(0.0113)\end{array}$ & $\begin{array}{c}0.0115 \\
(0.0108)\end{array}$ & $\begin{array}{c}0.0139 \\
(0.0106)\end{array}$ & $\begin{array}{c}0.0122 \\
(0.0123)\end{array}$ \\
\hline $\mathrm{AGR}_{-1}$ & $\begin{array}{l}-0.0494 \\
(0.0323)\end{array}$ & $\begin{array}{l}-0.0589^{*} \\
(0.0330)\end{array}$ & $\begin{array}{c}-0.0684^{* *} \\
(0.0330)\end{array}$ & $\begin{array}{l}-0.0535 \\
(0.0325)\end{array}$ & $\begin{array}{l}-0.0527 \\
(0.0337)\end{array}$ & $\begin{array}{l}-0.0307 \\
(0.0336)\end{array}$ & $\begin{array}{l}-0.0409 \\
(0.0337)\end{array}$ & $\begin{array}{l}-0.0226 \\
(0.0341)\end{array}$ & $\begin{array}{l}-0.0352 \\
(0.0316)\end{array}$ & $\begin{array}{c}-0.0554 \\
(0.0356)\end{array}$ \\
\hline $\mathrm{OPP}_{-1} \mathrm{X} \mathrm{REG}_{-1}$ & $\begin{array}{l}-0.0208^{*} \\
(0.0122)\end{array}$ & $\begin{array}{l}-0.00913 \\
(0.0115)\end{array}$ & $\begin{array}{l}-0.0216^{*} \\
(0.0123)\end{array}$ & $\begin{array}{l}-0.0209^{*} \\
(0.0124)\end{array}$ & $\begin{array}{l}-0.0210 \\
(0.0128)\end{array}$ & $\begin{array}{l}-0.0183 \\
(0.0125)\end{array}$ & $\begin{array}{l}-0.0188 \\
(0.0129)\end{array}$ & $\begin{array}{l}-0.0147 \\
(0.0127)\end{array}$ & $\begin{array}{l}-0.0172 \\
(0.0124)\end{array}$ & $\begin{array}{l}-0.0250^{*} \\
(0.0142)\end{array}$ \\
\hline $\mathrm{OPP}_{-1} \mathrm{X} \mathrm{AGR}_{-1}$ & $\begin{array}{l}0.00963 \\
(0.0238)\end{array}$ & $\begin{array}{c}0.0255 \\
(0.0271)\end{array}$ & $\begin{array}{c}0.0270 \\
(0.0244)\end{array}$ & $\begin{array}{c}0.0135 \\
(0.0240)\end{array}$ & $\begin{array}{l}0.00853 \\
(0.0245)\end{array}$ & $\begin{array}{l}-0.00351 \\
(0.0248)\end{array}$ & $\begin{array}{l}0.00161 \\
(0.0253)\end{array}$ & $\begin{array}{l}-0.0114 \\
(0.0247)\end{array}$ & $\begin{array}{l}-0.00506 \\
(0.0235)\end{array}$ & $\begin{array}{c}0.0182 \\
(0.0267)\end{array}$ \\
\hline REG-1 X AGR-1 & $\begin{array}{r}0.0420 * * \\
(0.0208) \\
\end{array}$ & $\begin{array}{r}0.0415 * * \\
(0.0196) \\
\end{array}$ & $\begin{array}{r}0.0498 * * \\
(0.0214)\end{array}$ & $\begin{array}{c}0.0417 * \\
(0.0214) \\
\end{array}$ & $\begin{array}{c}0.0432 * \\
(0.0222)\end{array}$ & $\begin{array}{l}0.0344 \\
(0.0217)\end{array}$ & $\begin{array}{r}0.0435 * * \\
(0.0219)\end{array}$ & $\begin{array}{l}0.0254 \\
(0.0226)\end{array}$ & $\begin{array}{l}0.0334 \\
(0.0208)\end{array}$ & $\begin{array}{r}0.0491 * * \\
(0.0229) \\
\end{array}$ \\
\hline $\mathrm{N}^{\circ}$ Observations & 7441 & 6567 & 6715 & 7009 & 6937 & 7047 & 6345 & 6683 & 6868 & 5902 \\
\hline Adj. $\mathrm{R}^{2}$ & 0.221 & 0.191 & 0.246 & 0.223 & 0.217 & 0.226 & 0.161 & 0.232 & 0.234 & 0.223 \\
\hline Sargan-Hansen & 6.031 & 5.454 & 6.044 & 6.784 & 5.270 & 7.154 & 4.647 & 4.262 & 5.761 & 4.607 \\
\hline $\begin{array}{l}\text { Sargan-Hansen p- } \\
\text { value }\end{array}$ & 0.420 & 0.487 & 0.418 & 0.341 & 0.510 & 0.307 & 0.590 & 0.641 & 0.450 & 0.595 \\
\hline
\end{tabular}


Table 5 - Robustness to alternative specification

\begin{tabular}{|c|c|c|c|c|}
\hline & $\begin{array}{c}\text { (1) } \\
\text { Reference } \\
\text { Equation }\end{array}$ & $\begin{array}{l}\text { (2) } \\
\text { Without year X } \\
\text { sector dummies }\end{array}$ & $\begin{array}{c}(3) \\
\text { Without } \Delta \\
\text { value added }\end{array}$ & $\begin{array}{c}\text { (4) } \\
\text { without wages }\end{array}$ \\
\hline$\Delta$. Value added $(\log )$ & $\begin{array}{l}0.279^{* * * *} \\
(0.0229)\end{array}$ & $\begin{array}{l}0.275^{* * * *} \\
(0.0239)\end{array}$ & & $\begin{array}{l}0.291^{* * * * *} \\
(0.0227)\end{array}$ \\
\hline Wage per head $(\log )$ & $\begin{array}{l}0.259^{* * *} \\
(0.0328)\end{array}$ & $\begin{array}{l}0.268^{* * *} \\
(0.0366)\end{array}$ & $\begin{array}{l}0.305^{* * *} \\
(0.0354)\end{array}$ & \\
\hline $\begin{array}{l}\text { Worforce or union opposition } \\
\left(\mathrm{OPP}_{-1}\right)\end{array}$ & $\begin{array}{c}0.0038 \\
(0.0080)\end{array}$ & $\begin{array}{c}0.0028 \\
(0.0087)\end{array}$ & $\begin{array}{c}0.0029 \\
(0.0092)\end{array}$ & $\begin{array}{c}0.00234 \\
(0.00823)\end{array}$ \\
\hline $\begin{array}{l}\text { Skills, supply or technical } \\
\text { constraints }\left(\mathrm{TEC}_{-1}\right)\end{array}$ & $\begin{array}{l}-0.00576 \\
(0.00737)\end{array}$ & $\begin{array}{l}-0.0023 \\
(0.0078)\end{array}$ & $\begin{array}{l}-0.0023 \\
(0.0086)\end{array}$ & $\begin{array}{l}-0.00584 \\
(0.00756)\end{array}$ \\
\hline Regulatory constraints $\left(\mathrm{REG}_{-1}\right)$ & $\begin{array}{c}0.0119 \\
(0.0106)\end{array}$ & $\begin{array}{c}0.0128 \\
(0.0118)\end{array}$ & $\begin{array}{c}0.0123 \\
(0.0124)\end{array}$ & $\begin{array}{c}0.0111 \\
(0.0109)\end{array}$ \\
\hline Branch or firm agreement $\left(\mathrm{AGR}_{-1}\right)$ & $\begin{array}{l}-0.0494 \\
(0.0323)\end{array}$ & $\begin{array}{l}-0.0576 \\
(0.0351)\end{array}$ & $\begin{array}{l}-0.0632^{*} \\
(0.0375)\end{array}$ & $\begin{array}{l}-0.0547^{*} \\
(0.0329)\end{array}$ \\
\hline $\begin{array}{l}\text { Worforce or union opposition and } \\
\text { regulatory constraints }\left(\mathrm{OPP}_{-1} \mathrm{X}\right. \\
\left.\mathrm{REG}_{-1}\right)\end{array}$ & $\begin{array}{l}-0.0208^{*} \\
(0.0122)\end{array}$ & $\begin{array}{l}-0.0262^{*} \\
(0.0141)\end{array}$ & $\begin{array}{l}-0.0214 \\
(0.0141)\end{array}$ & $\begin{array}{l}-0.0210^{*} \\
(0.0125)\end{array}$ \\
\hline $\begin{array}{l}\text { Worforce or union opposition and } \\
\text { branch or firm agreement (OPP } \\
{ }_{1} \mathrm{X} \mathrm{AGR}_{-1} \text { ) }\end{array}$ & $\begin{array}{l}0.00963 \\
(0.0238)\end{array}$ & $\begin{array}{l}0.00172 \\
(0.0235)\end{array}$ & $\begin{array}{c}0.0229 \\
(0.0274)\end{array}$ & $\begin{array}{c}0.0143 \\
(0.0242)\end{array}$ \\
\hline $\begin{array}{l}\text { Regulatory constraints and branch } \\
\text { or firm agreement }\left(\mathrm{REG}_{-1} \mathrm{X} \text { AGR }\right. \\
\text { 1) }\end{array}$ & $\begin{array}{l}0.0420^{* *} \\
(0.0208)\end{array}$ & $\begin{array}{c}0.0649^{*} \\
(0.0394)\end{array}$ & $\begin{array}{l}0.0427^{*} \\
(0.0243)\end{array}$ & $\begin{array}{l}0.0432^{* *} \\
(0.0213)\end{array}$ \\
\hline $\mathrm{N}^{\circ}$ Observations & 7,441 & 7,441 & 7,441 & 7,441 \\
\hline Adj. $R^{2}$ & 0.221 & 0.131 & -0.0673 & 0.188 \\
\hline Sargan-Hansen & 6.031 & 14.02 & 4.574 & 6.562 \\
\hline Sargan-Hansen p-value & 0.420 & 0.232 & 0.600 & 0.363 \\
\hline
\end{tabular}

Robust standard errors in parentheses

${ }^{*} p<0.1,{ }^{* *} p<0.05,{ }^{* * *} p<0.01$

Firm fixed effects when specified, two stage least square estimates, generalized method of moments. Lagged levels and lagged difference of obstacles used as instruments. Year, Sector X Year dummies when specified and constant included but not reported. 